\title{
Sexual and asexual reproductive aspects of Leontochir ovallei, a rare and endangered geophyte of the Atacama Desert
}

Marta Vargas ${ }^{1 \dagger}$, Elda Jofré ${ }^{1 \dagger}$, Carlos Navarrete ${ }^{2}$, Jaime Bravo ${ }^{3}$, Fabiola Jamett ${ }^{4}$, Claudio Inostroza-Blancheteau ${ }^{5}$ and Cristian Ibáñez ${ }^{1 *}$

\begin{abstract}
Background: "Garra de Leon" (Leontochir ovallei) is an ephemeral endangered Alstroemeriaceae species endemic to Chile. Despite many efforts to improve the conservation of this species, the stimulation of dormant seeds and the production of rhizomes under controlled conditions remain unexplored. The aims of this study were to examine the germination responses of $L$. ovallei seeds under different in vitro conditions and to evaluate the formation of viable rhizomes after transplantation from in vitro to ex vitro conditions.

Methods: We evaluated five in vitro seed germination treatments: (1) acid scarification, (2) acid scarification followed by imbibition of seeds in aerated water, (3) imbibition of seeds in gibberellic acid, (4) clipping of seeds with a scalpel, and (5) seeds without any treatment (control). Seedlings obtained under in vitro conditions were transplanted to ex vitro conditions following a gradual acclimation process. After eight months, the number of rhizomes per plant was counted. To test asexual multiplication, each rhizome with its respective storage organ was divided using a scalpel and then left to rest for two years before subsequent evaluation of viability. After that period, the rhizomes were re-hydrated, and the emergence of plants after three months was evaluated.

Results: Seeds exposed to treatment 2 showed the highest germination percentage (36\%), followed by the seeds whose coats were clipped (14\%) and seeds treated with sulphuric acid (8\%). The seed germination of the control treatment was 3\%. After transplantation to ex vitro conditions, we obtained 220 rhizomes, with an average of three to six rhizomes per plant. After two years of dormancy, a total of 34 rhizomes (of 220 rhizomes) reactivated growth after re-ydration, indicating that, at least, 15,5\% responded positively to watering.

Conclusions: We found that the seed germination of L. ovallei was increased by strong acidic conditions, suggesting that the main type of seed dormancy in this species is physical. However, germination was further increased by aeration, indicating embryo dormancy. In addition, we were able to obtain viable rhizomes by transplanting seedlings from in vitro to ex vitro conditions, which may be helpful for the propagation and ex situ conservation of this rare geophyte of Chile and potentially other geophyte species adapted to wet-dry cycle environments.
\end{abstract}

Keywords: Blooming desert, Alstroemeriaceae, In vitro seed germination, Rhizome production, Ex-situ conservation

\footnotetext{
* Correspondence: cibanez@userena.cl

${ }^{\dagger}$ Equal contributors

'Departamento de Biología, Facultad de Ciencias, Universidad de La Serena,

P.O. 1700000 La Serena, Chile

Full list of author information is available at the end of the article
}

(c) The Author(s). 2018 Open Access This article is distributed under the terms of the Creative Commons Attribution 4.0 International License (http://creativecommons.org/licenses/by/4.0/), which permits unrestricted use, distribution, and reproduction in any medium, provided you give appropriate credit to the original author(s) and the source, provide a link to the Creative Commons license, and indicate if changes were made. The Creative Commons Public Domain Dedication waiver (http://creativecommons.org/publicdomain/zero/1.0/) applies to the data made available in this article, unless otherwise stated. 


\section{Background}

Geophytes are a dominant component of arid plant communities. Their survival in these water-limited environments depends on two important aspects. First, geophytes bury underground storage organs with perennial buds such as bulbs, rhizomes, roots tubers and corms. Under favourable environmental conditions, these buds re-sprout, and photosynthesis activates the replenishment of storage reserves to enable new life cycles $[1,2]$. This aspect ensures that plant communities will not only persist but also continuously colonize the environment. Second, geophytes (like many other plants) must maintain reproduction based on seeds to ensure genetic variability and gene flow between and among populations [3]. This strategy is pivotal for plants to expand their area of distribution and, more importantly, to transmit to the next generation information on how to survive in harsh environments. Therefore, further knowledge on the seed biology of geophytes will improve the likelihood of devising conservation or commercial strategies for this important arid plant community. However, studies of the propagation of non-domesticated geophytes remain scarce.

In Chile, geophytes are represented by more than 40 genera, of which 19 are endemic [4]. Alstroemeriaceae species are among the most valuable geophytes for ornamental purposes; however, species of this family exhibit low, slow and erratic seed germination [5]. This characteristic hampers efforts for their domestication and ex situ conservation. However, through seed propagation a substantial number of seedlings can be produced, accelerating the propagation of species. Here, we present the study case of Leontochir ovallei as a study model to investigate the aforementioned gaps.

The ephemeral Garra de León (Leontochir ovallei Phil) is the most iconic flower of the Atacama blooming desert [6]. Leontochir ovallei is a rare monogeneric monocotyledon of the Alstroemeriaceae family that is endemic to a very narrow area of the Atacama Desert in Chile. To complete the flower's developmental process, at least three cycles of El Niño events (15 to 21 years) might be required mainly because these plants require two or more seasons to become established, develop and produce mature viable seeds [7]. In addition to its limited distribution and the environmental stochasticity in water availability, this plant species is subjected to other threats. Its inflorescences are eaten by hares and massively collected by local people for commercial or landscape gardening purposes [7, 8]. As a consequence, and following the Red List criteria of the International Union for Conservation of Nature [9], $L$. ovallei is currently classified as an endangered species in Chile [10-14]. Accordingly, the establishment of propagation programmes to assist conservation strategies for this plant has become a concern for governmental agencies and conservationists $[15,16]$.
The potential role of seed germination in maintaining L. ovallei populations remains largely unexplored. Only one previous study investigated the germination of $L$. ovallei seeds, but did not report seed germination requirements [17]. Asexual propagation of Alstroemeriaceae species by dividing their rhizomes is the method most frequently used [18]. However, this strategy is not easy to achieve in the case of $L$. ovallei, because the rhizomes are deeply buried or settled under heavy rocks, making it almost impossible to obtain undisturbed rhizomes [5]. Cultivation of the elusive rhizomes of this species has not been reported.

In vitro methods have been successful for Alstroemeriaceae species [19-21], including micropropagation [22, 23]. To achieve successful propagation using in vitro methods for any plant species, the growth media, $\mathrm{pH}$, incubation temperature, light conditions, and type and concentration of hormones must be optimized [24, 25]. The stratification/ scarification methods used to stimulate seed germination [26] are also pivotal factors that require optimization. In the case of $L$. ovallei, little is known regarding the optimal conditions for the plant's in vitro propagation.

The aim of this study is to evaluate in vitro and ex vitro methods of propagation of L. ovallei. Specifically, the aims were to (a) determine the in vitro germination responses to five pre-sowing treatments; (b) evaluate the success of transplanting seedlings from in vitro to ex vitro conditions; and c) evaluate rhizome formation and viability of $L$. ovallei under ex vitro conditions.

\section{Methods}

\section{Species description}

Leontochir ovallei Phil. is restricted to a limited area $\left(500 \mathrm{~km}^{2}\right)$ on the coast of the Atacama Desert between Carrizal Bajo $\left(28^{\circ} 05^{\prime} \mathrm{S}, 71^{\circ} 09^{\prime} \mathrm{W}\right)$ and the town of Totoral (27 $\left.544^{\prime} \mathrm{S}, 70^{\circ} 57^{\prime} \mathrm{W}\right)$ [8, 10, 27, 28], where it forms patches of small populations that are usually isolated from each other (Additional file 1A). This scandent geophyte grows preferentially on rocky slopes and produces highly attractive reddish-orange inflorescences (which might also be yellow in rare cases [29]) that can easily reach a diameter of $10 \mathrm{~cm}$ and a height of $1 \mathrm{~m}$ (Additional file 1A). Due to the heavy weight of its inflorescences, Garra de León typically acquires a climbing habit, and its seeds are spread through an explosive dehiscent strategy $[5,30]$.

\section{Seed collection and storage}

The ephemeral L. ovallei blossomed in the spring of 2011 after unusual precipitation of $50 \mathrm{~mm}$ from May to June [31]. Seed collection was conducted from December 2011 to February 2012 (summer in the Southern Hemisphere) in Llanos de Challe National Park (2809' S, $\left.71^{\circ} 04^{\prime} \mathrm{W}\right)$. Due to the endangered status of this species, we followed 
the Guidelines of the IUCN Policy Statement on Research Involving Species at Risk of Extinction [14]. To avoid herbivores (and collectors), 100 inflorescences were randomly chosen and fully covered with paper bags from December (when the fruits were dried-out and before bursting) to January (Additional file 1B). With this simple technique, we collected $100 \%$ of the seeds contained in the inflorescences (ca. 5000 seeds in total; Additional file 1C). Conversely, explosive dehiscence was not prevented in the inflorescences that were not protected with paper bags, and most of these seeds were expelled and eaten by wild animals. The rest of the petals and other floral structures were manually eliminated from seeds. No water was used during this cleaning process. Clean seeds were treated with a commercial antifungal powder (Captan $10 \mathrm{~g} / \mathrm{L}$ by ANASAC) for $2 \mathrm{~h}(\mathrm{~h})$ and then dried at $35{ }^{\circ} \mathrm{C}$ in a forcedair chamber until reaching a constant weight. The seeds were subsequently stored in several propylene tubes at $4^{\circ}$ $\mathrm{C}$ for at least three months prior to use.

\section{In vitro seed germination treatments}

Based on the results of preliminary assessments (Additional file 2), seeds of $L$. ovallei that had been cold stratified for three months were disinfected with $70 \%$ ethanol for $1 \mathrm{~min}(\mathrm{~min})$ and subsequently with $\mathrm{NaClO}$ (1.5\%) for $10 \mathrm{~min}$; the seeds were then rinsed four times with distilled water.

Five in vitro seed germination treatments were evaluated following a completely random design, where each treatment included 10 replicates, and each replicate included $10 \mathrm{~L}$. ovallei seeds (Table 1 ). In all treatments, the seeds were germinated at $25 \mu \mathrm{mol} \mathrm{m} \mathrm{m}^{-2} \mathrm{~s}^{-1}$ PAR. The treatments were as follows: treatment $\# 1,4$ min soaking in $25 \mathrm{~mL}$ of sulphuric acid at $22^{\circ} \mathrm{C}\left( \pm 3{ }^{\circ} \mathrm{C}\right)$; treatment $\# 2$, 4 min soaking in sulphuric acid (as above) followed by soaking in $250 \mathrm{~mL}$ of distilled water enriched in atmospheric air supplied by an air pump (Regent Calm, Series RC-006) for $48 \mathrm{~h}$; treatment \#3, soaking in gibberellic acid $\left(\mathrm{GA}_{3}, 5 \mathrm{mg} / \mathrm{L}\right)$ without acid treatment for $72 \mathrm{~h}$, followed by soaking in $250 \mathrm{~mL}$ of distilled water rich in atmospheric air supplied by an air pump for $48 \mathrm{~h}$; treatment \#4, soaking in $250 \mathrm{~mL}$ of distilled water for $48 \mathrm{~h}$, and followed by clipping of the seed coat with a scalpel; and treatment \#5, no pre-sowing treatment (control treatment). The seeds were transferred to Petri dishes containing $25 \mathrm{~mL}$ of culture media, which in turn were placed in a growth chamber (Additional file 1D). Culture medium was prepared using Murashige and Skoog (MS) medium (PhytoTechnology Inc., product code M519-Info) supplemented with $2 \%$ sucrose, 6-benzylaminopurine (6-BAP; 0 . $5 \mathrm{mg} / \mathrm{L}), \mathrm{NaCl}(20 \mu \mathrm{M})$ and agar $(8 \mathrm{~g} / \mathrm{L}), \mathrm{pH}$ 5.8. The medium was autoclaved at $121{ }^{\circ} \mathrm{C}$, with a pressure of $1 \mathrm{~kg} / \mathrm{cm}^{2}$ for $20 \mathrm{~min}$. The medium was then poured into 90-mm Petri dishes. The photoperiod in the growth chamber was $16 \mathrm{~h} / 8 \mathrm{~h}$ (day/night), the light intensity was $100 \mu \mathrm{mol} \mathrm{m}{ }^{2} \mathrm{~s}^{-1}$ PAR, and the temperature was set constant at $21{ }^{\circ} \mathrm{C}$. A seed was considered germinated when its radicle reached at least $3 \mathrm{~mm}$ [32]. Seed germination was recorded at midday once per week for 100 days and expressed as the percentage of germination and the odds ratios (O.R) for germination. Germination (O.R.) is the quotient of the odds for germination in each group compared with the control group.

\section{Transplantation of seedlings from in vitro to ex vitro conditions}

For L. ovallei, there is no information about the success of transplantation from in vitro to ex vitro conditions. To evaluate this (objective b), 65 seedlings with a height of approximately $2.5 \mathrm{~cm}( \pm 0.5 \mathrm{~cm})$ and at least three leaves were randomly selected from the different germination treatments and carefully transplanted into $250-\mathrm{cm}^{3}$ plastic pots containing a sterile sand:vermiculite (2:1) mixture. Seedlings of $L$. ovallei suffer rapid dehydration after transplantation. Hence, a second plastic pot was used to completely cover the first pot (Additional file 1E). Exposure to chamber air was performed every 15 days, and at day 45, the second plastic pot was completely removed. The seedlings were grown for three months in a growth chamber under conditions identical to those used for germination (see

Table 1 Effect of pre-sowing treatments on seed germination of L. ovallei after 100 days ofo incubation. Seeds were subjected to the following treatments: treatment \#1= sulphuric acid $\left(\mathrm{H}_{2} \mathrm{SO}_{4}\right)$; treatment $\# 2=$ sulphuric acid and imbibing in aerated water $(\mathrm{Ox})$ for $48 \mathrm{~h}$; treatment $\# 3=$ gibberellic acid $\left(\mathrm{GA}_{3}\right)$ and soaking in aerated water for $48 \mathrm{~h}$; and treatment \#4= soaking in water for $48 \mathrm{~h}$ and clipping (cut). Germination (O.R.) is the quotient of the odds of germination in each group compared with the control group. $P$ values correspond to likelihood ratio tests $(n=10)$

\begin{tabular}{llllll}
\hline Pre-sowing treatment codes & Details of treatments & Germination (\%) & $\begin{array}{l}\text { O.R. for germination ratio } \\
\text { compared with control }\end{array}$ & Confidence interval (95\%) & $P$ \\
\hline Treatment \#1 & $\mathrm{H}_{2} \mathrm{SO}_{4}$ & 8.0 & 2.8 & 1.35 .4 & $12.0-27.2$ \\
Treatment \#2 & $\mathrm{H}_{2} \mathrm{SO}_{4}+\mathrm{Ox}$ & 36.0 & 18.2 & $0.4-3.2$ & $<0.01$ \\
Treatment \#3 & $\mathrm{GA}_{3}+\mathrm{Ox}$ & 4.0 & 1.3 & $2.9-9.0$ & N.S. \\
Treatment \#4 & Cut & 14.0 & 5.3 & - & $<0.0001$ \\
Treatment \#5 & Control & 3.0 & 1.0 & - \\
\hline
\end{tabular}


above). The seedlings that survived after these three months were counted and the percentage of survival relative to the initial number of seedlings transplanted was calculated. After these three months of gradual acclimation inside the growth chamber (Additional file 1F), the seedlings that survived were carefully re-potted in a mixture of sand:nutritive soil (3:1) and transferred to a greenhouse (objective c) to evaluate survival (second part of objective b) and rhizome formation (objective c) after eight months. The nutritive soil was a mix of soil and forest industry residues containing more than $20 \%$ of organic matter, $30-45 \%$ humidity, a $\mathrm{C} / \mathrm{N}$ ratio less than 5.0 , electric conductivity of $3 \mathrm{ds} / \mathrm{m}$, bulk density of $0.55-0.75 \mathrm{k} / \mathrm{L}, \mathrm{pH} 5.0-8.5$ and inert material of less than $5 \%$ (ANASAC). In the greenhouse, the seedlings were grown at day/night temperatures of $30{ }^{\circ} \mathrm{C} / 15{ }^{\circ} \mathrm{C}$, respectively, with $70-60 \%$ humidity and a natural photoperiod ranging from October/November ( $13 \mathrm{~h}$ of daylight) to June/ July ( $10 \mathrm{~h}$ of daylight) and $350 \mu \mathrm{mol} \mathrm{m} \mathrm{m}^{-2} \mathrm{~s}^{-1}$ PAR $18 \mathrm{~h}$ per day. The seedlings were watered $(\sim 20 \mathrm{~mL})$ once a week during the first month and every 21 days for eight months. This was intended to mimic the putative wet-dry cycle of this plant species in nature. The expected phenological stages of $L$. ovallei based on observations from our research group indicate that a seed typically germinates in September (after winter rains). Seedlings then grow vigorously during spring (October to December) until dehydration through summer. By the end of autumn/beginning of winter, rhizomes should be formed.

\section{Rhizome formation}

After eight months, the seedlings were carefully removed from their pots (Additional file 3A), and the total number of rhizomes and the number of rhizomes per plant formed was counted (Additional file 3B). To evaluate viability, the rhizomes were separated using a scalpel; each rhizome remained attached to its storage organ (Additional file 3C). Each rhizome was then buried in a pot with fresh sand:nutritive soil (3:1) at $3 \mathrm{~cm}$ belowground for two years in the greenhouse. During these two years, the pots were exposed to temperatures, humidity and light conditions occurring naturally in La Serena throughout the year (Additional file 4). Watering of pots was completely suspended during this resting period, again mimicking natural climatic conditions for geophytes in the Atacama Desert. After two years, the viability of the rhizomes was evaluated by watering the pots daily with $\sim 50 \mathrm{~mL}$ of tap water every three days for one month (Additional file 3D). The chemical composition of the tap water used in this stage is shown in Additional file 5. The number of emerged vs non-emerged seedlings were evaluated by counting the emergence of new shoots during the entire reactivation time period and presented as the percentage of re-sprouting. When a shoot reached $5 \mathrm{~mm}$, we considered that rhizome viable.

\section{Statistical analysis}

Common statistical models for time-to-event data (e.g., accelerated failure times, Cox's proportional hazards model) are difficult to adapt to germination studies because all events ("death" in survival applications) are assumed to occur at a finite time. In germination studies we are interested in the event of seed germination, and the possibility that a proportion of seeds will never germinate must be considered. From the perspective of survival applications, a time-to-event model that considers the probability of no occurrence of the event is called a cure model. We considered five treatments, $j=0,1,2,3$, 4 , where $j=0$ represents a reference treatment, in our case Control. For a treatment $j, p_{j}$ denotes the overall probability of germination and, conditional on the event of germination, $\lambda_{j}$ is the germination rate. Since our observations are interval-censored, $\left(t_{0, i}, t_{1}, i\right)$ is the time interval when germination occurs. The maximum likelihood estimation of the parameters based on an exponential probability density for the germination times, was obtained by means of maximizing the function

$$
\begin{aligned}
& L(p, \lambda)=\sum_{j=0}^{4}\left\{n_{j} \ln \left(p_{j}\right)+\right. \\
& \left.\sum_{i=1}^{n_{j}} \ln \left(e^{-\lambda_{j} t_{0, i}}-e^{-\lambda_{j} t_{1, i}}\right)+\left(100-n_{j}\right) \ln \left(1-p_{j}\right)\right\},
\end{aligned}
$$

where $n_{j}$ is the observed number of germinated seeds for treatment $j$. We further consider the logistic formulation $\ln \left(p_{j}\right)=\alpha_{0}+\alpha_{j}-\ln \left(1+e^{\alpha_{0}+\alpha_{j}}\right)$ for $j>0$ and $\ln \left(p_{0}\right)$ $=\alpha_{0}-\ln \left(1+e^{\alpha_{0}}\right)$, and $\lambda_{j}=\beta_{0}+\beta_{j}$ for $j>0, \lambda_{0}=\beta_{0}$ for $j>$ 0 for the germination rates. Parameters $\alpha$ and $\beta$ are defined for the purpose of evaluating treatment effects and their comparison. We compared treatments in overall germination in terms of the odds ratios (O.R.), defined as $p_{j} /$ $\left(1-p_{j}\right) p_{0} /\left(1-p_{0}\right)$. Thus, O.R. $=1$ when there is no difference between group $\mathrm{j}$ and the control group, and germination rates conditional to observing germination were used to compare overall germination under the different treatments at the same scale. Statistical differences among treatments were evaluated by means of likelihood ratio tests, adjusting $p$-values for multiple comparisons with the method of Benjamini, Hochberg, and Yekutieli [33]. Maximization was conducted using the "L-BFGS-B" method [34]. All statistical analyses were performed using $R$ version 3.4.2 [35]. To evaluate the success of transplantation from in vitro to ex vitro conditions we compared the observed survival with a reference proportion of $50 \%$ using a Chi-square test. $P$ values were estimated by both asymptotic and Monte Carlo methods to ensure that the approximation was correct. The number of rhizomes counted in the surviving plants after transplantation was described by absolute frequencies. 


\section{Results}

\section{Seed germination}

Treatment \#2 (sulphuric acid and aerated water for $48 \mathrm{~h}$ ) showed the highest germination percentage (36\%) (Table 1 ) and it was the only treatment that showed seeds germination after 10 days (Fig. 1). Treatment \#4 (soaked in water for $48 \mathrm{~h}$ and then coat-clipped) and treatment \#1 (sulphuric acid only) showed intermediate germination percentages (14\% and $8 \%$, respectively). In both cases, germination started one week later (day 15) than in treatment \#2. Treatment \#3 (gibberellic acid (GA) and aerated water for $48 \mathrm{~h}$ ) showed $4 \%$ germination, and germination also began on day 15, whereas treatment \#5 (control treatment) presented the lowest percentage of seed germination, only $3 \%$, and its germination started only after 30 days. For all of these treatments (including the control treatment), germination was halted approximately two months postincubation (Fig. 1).

The cure model ( $95 \%$ C.I.) indicated that three of the five pre-sowing treatments had a significant effect $(p<0$. 001 ) on the percentage of germination and days until germination compared with the control treatment (Table 1 ). Thus, the seeds subjected to treatment \#2 presented an O.R. of germination of $18.2(12.0 ; 27.2)$ compared with those subjected to the control treatment. The O.R. for germination observed for the seeds treated with treatment \#4 was $5.3(2.9 ; 9.0)$ higher, whereas O.R. of 2. $8(1.3 ; 5.48)$ and $1.3(0.4 ; 3.2)$ were observed for the seeds subjected to treatment \#1 and treatment \#3 (not statistically significant), respectively (Table 1).

\section{Survival after transplanting from in vitro to ex vitro conditions and subsequent rhizome formation}

The first stage of the gradual acclimation (three months inside a growth chamber) revealed that 45 of the 65 seedlings survived transplantation from in vitro to ex vitro conditions $(p=0.05)$. This represents $69.2 \%$. Following the second stage of acclimation (eight months in a greenhouse), only 36 of the 45 seedlings survived $(p<$ 0.001 ), representing $80 \%$ success. Overall, if we compare the number of seedlings initially transferred from in vitro to ex vitro conditions (65 seedlings) and the number of plants that survived at the end of this greenhouse stage (36 seedlings), we obtained seedling survival of $55.4 \%$. The 9 seedlings that did not survive this stage of acclimation died early (at the third week). In terms of rhizome formation, the surviving seedlings formed a total of 220 rhizomes, with 1 to 16 rhizomes per seedling (Fig. 2). In addition, $67 \%$ of the seedlings (24 out of 36) presented between 3 and 6 rhizomes (Fig. 2 and Additional file 3B). Assuming that each rhizome represents a potential new plant, and that only one rhizome was

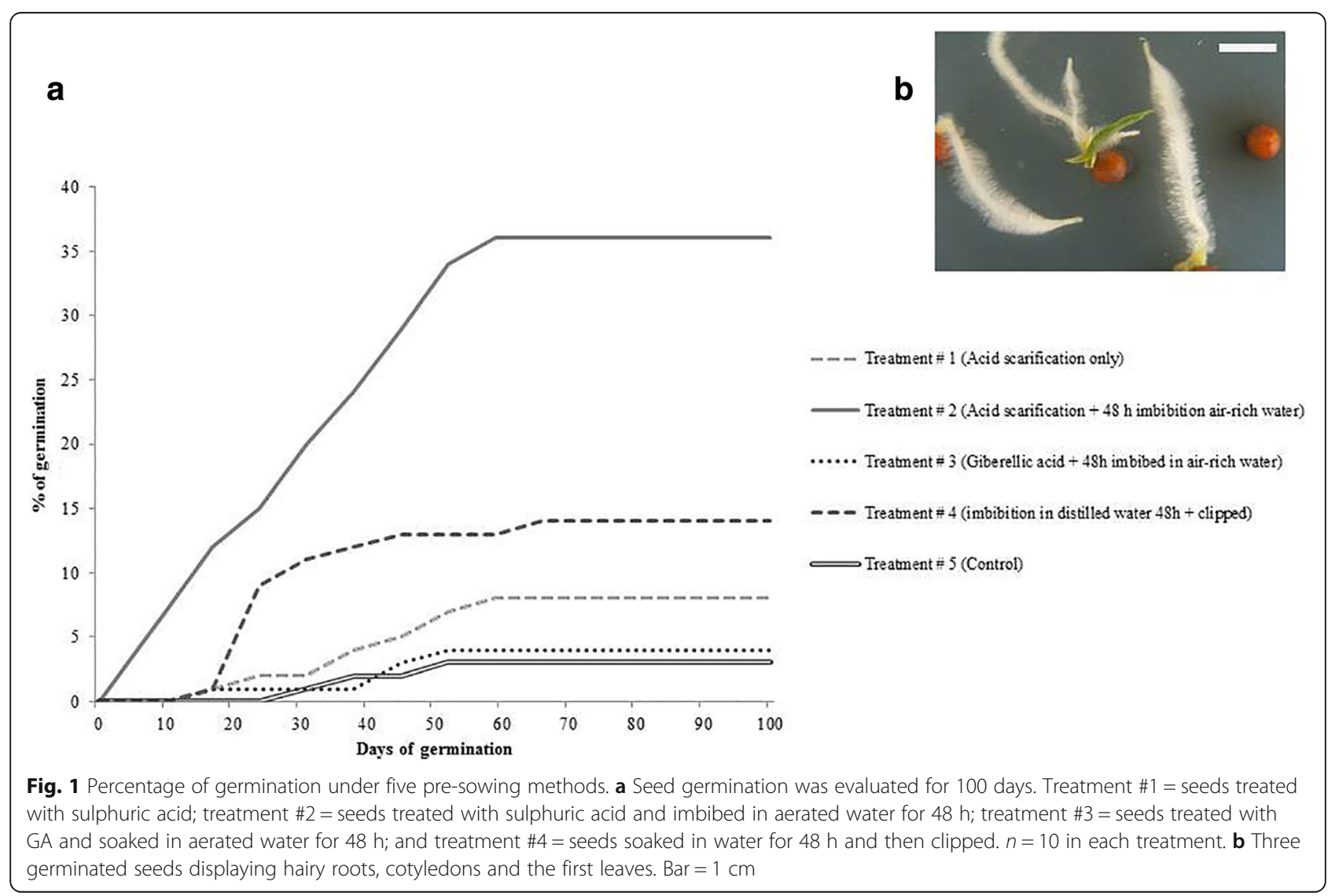




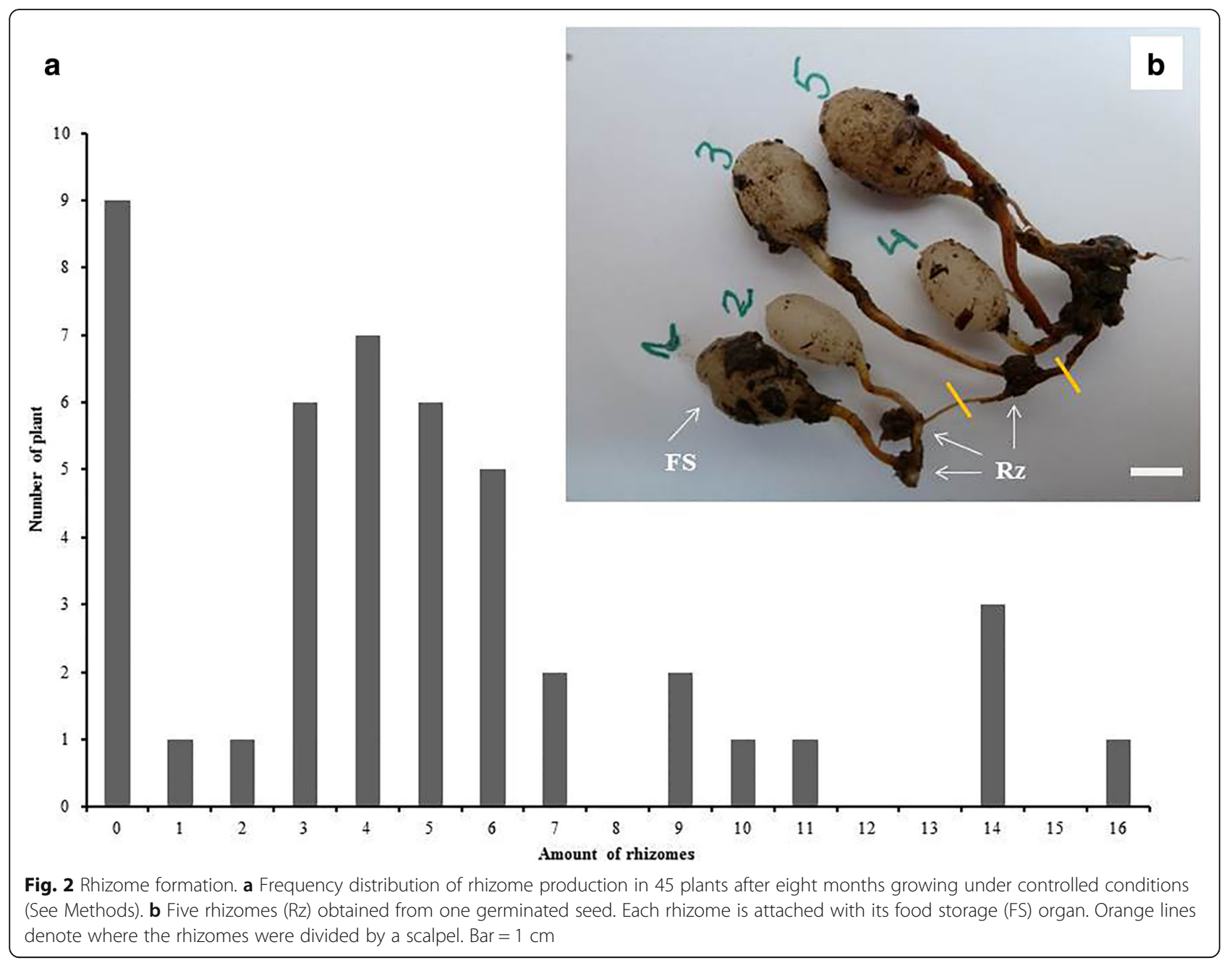

formed when the plants were transferred to the greenhouse at the beginning of the second stage, our results indicate an increase in rhizomes equivalent to $488 \%$ in eight months. After two years of resting, rehydration reactivated the growth of 34 of 220 rhizomes (15.5\%; Additional file 3D).

\section{Discussion}

\section{Pre-sowing treatment effects}

This study shows that the germination of Leontochir ovallei is significantly increased by different pre-sowing treatments. Previous studies of Chilean geophytes growing from semiarid to Mediterranean areas and from the Pacific coast to the Andes mountain limits of their distribution have reported that seed germination in several species of Alstroemeriaceae (e.g., Alstroemeria pseudospathulata and Bomarea salsilla) is stimulated by treatments similar to those used in this study (i.e., cold stratification, acid scarification, water imbibition, use of gibberellic acid and clipping of seed testa), indicating the effectiveness of these treatments for breaking physical and chemical dormancy [36-42], in contrast to the results for L. ovallei. According to our results, non-clipped seeds treated with sulphuric acid (treatment \#1) exhibited partially improved seed germination. Seed germination increased only when these acid- treated seeds were soaked in aerated water (treatment \#2), showing that this combination was the most effective treatment for $L$. ovallei seeds. This result might be attributed to the positive effect of sulphuric acid by destroying the wax layers and suberin of the seed coats, which favours water absorption and gas exchange (mainly oxygen) in the seed $[43,44]$. The subsequent provision of atmospheric airenriched water likely improved this gas exchange, which in turn might have increased the oxygen availability for the embryo [45]. Most seeds of vascular plants are restricted by water availability in the soil and by the amount of oxygen dissolved in the water that can enter the seed $[1,46]$. The increase in germination due to exogenous aeration might indicate that $L$. ovallei seeds exhibit embryo dormancy as well as physical dormancy, which has been proposed to occur in the seeds of some 
species of the Alstroemeriaceae family [18]. Oxygen activates the oxidation of starch, lipids and proteins and stimulates the mobilization of several proteins that provide energy to sustain germination and embryo emergence and development [47-49]. L. ovallei appears to be a species whose seeds exhibit a high oxygen requirement. This high oxygen requirement could be a survival strategy used by geophytes distributed in arid lands to permit a decrease in the levels of endogenous oxygen in the seeds to a condition of hypoxia to minimize mitochondrial respiration. Germination would then be stimulated once sufficient water and oxygen pass into the seed [50, 51]. The optimization of the level of endogenous oxygen might help $L$. ovallei maintain a longer dormant state and avoid sprouting until the arrival of rain, which is always scarce and erratic in its arid environment.

Among the other three seed germination treatments, the germination percentage increased for seeds whose coats were soaked in distilled water for $48 \mathrm{~h}$ and clipped (treatment \# 4) compared to the control (treatment \# 5). This suggests that cutting might induce an important modification at the seed coat level (e.g., relaxing the physical tension imposed in the cell wall by the cell wall proteins, cellulose and lignin) [52-54]. By contrast, when seeds of L. ovallei were merely treated with acid (treatment \# 1), the physical barrier imposed by the seed coat was only partially reduced and the percentage of germination was similar to the reported for Alstroemeria magnifica (approximately 9\%) [55]. The germination of $L$. ovallei obtained with acid scarification was quite low compared with the germination of other plants adapted to arid lands, which can be close to $98 \%$ after acid scarification in the case of woody leguminous plants such as Prosopis juliflora and Acacia nilotica [52, 53, 56]. This finding suggests that factors other than the waterproof coats must be removed to enable full germination of the seeds of this species and perhaps other family members, highlighting the potential role of aeration during water imbibition of these seeds. GA is a hormone that stimulates seed germination [57], although it was not effective in the present study. Because we did not subject the seeds imbibed in GA(treatment \# 3) to acid scarification, the hard coat of the seeds likely impaired the proper absorption of GA. GA can act in two ways: by increasing the potential for embryo growth and by inducing hydrolytic enzymes $[58,59]$. Both processes might not have occurred in our $L$. ovallei seeds due to their reduced permeability. A future approach for seed germination in this species should consider pre-treatment with acid before GA.

\section{Seedling survival and rhizome production}

Acclimation of seedlings transplanted from in vitro to ex vitro conditions is a critical step in any program of plant propagation by in vitro means, mainly because in vitro leaves have thin cuticles and scarce stoma regulation, which favours a high rate of transpiration and in turn increases the risk that the seedlings will suffer high dehydration [60]. After 15 days of acclimation of Alstroemeria ligtu, $80 \%$ of seedlings survived [61], whereas for the hybrid Alstroemeria pelegrina $\mathrm{x}$ A pulchella this percentage was $87 \%$ after three months of acclimation [62]. In our case, the seedling survival of $L$. ovallei was almost $70 \%$ after three months of acclimation inside the growth chamber and $55 \%$ at the end of the acclimation process (greenhouse), which demonstrates that some Alstroemeriaceae species have a good response to the acclimation process.

We obtained healthy rhizomes of $L$. ovallei after transfer from in vitro to ex vitro conditions and were able to propagate them using asexual methods. Furthermore, the L. ovallei rhizomes obtained under controlled conditions maintained their viability after two years of dormancy. This study is the first to describe an in vitro/ex vitro methodology that successfully produces $L$. ovallei rhizomes. Few studies have reported the production of rhizomes in the Alstroemeria genus. For instance, using the rhizomesplitting technique, Chiari and Bridgen [63] achieved an increase in the number of propagules equivalent to $200 \%$ over a period of three months in Alstroemeria species. In our case, starting from seeds, we managed to increase the number of rhizomes by approximately $450 \%$. Notably, we did not split the rhizomes in half, in contrast to Chiari and Bridgen. Instead, we split between rhizomes, maintaining the attachment of the entire rhizome it its respective storage organ. Keeping the storage organ attached to the rhizome may be more beneficial for increasing the number of rhizomes than splitting the rhizome in half. Additionally, we used a mix of sand:nutritive soil (3:1) as substrate during rhizome formation, which may also have contributed to the development of new rhizomes in $L$. ovallei seedlings because the predominant soils in the natural habitat of this species are sandy soils [64] and our soil mix used for rhizome production was rich in this material. Aeration and percolation of water are two processes that might be favoured using sand as a substrate, and the formation of rhizomes by $L$. ovallei may be demanding with respect to these two conditions. Our next challenge is to evaluate methods for the reintegration of $L$. ovallei rhizomes in their native habitats and to elucidate the genetic aspects involved in the formation of rhizomes of this plant, considering the high variability observed in the number of rhizomes formed by plants.

\section{Conclusions}

In this study we reported for the first time in vitro seed germination of $L$. ovallei. The combination of acid scarification followed by seed imbibition in atmospheric air-rich water was essential to induce germination, suggesting a complex control of dormancy of the seeds of this species. This study also demonstrates that transferring $L$. 
ovallei seedlings from in vitro to ex vitro conditions is possible following a gradual acclimation process first in a growth chamber and then in a greenhouse. In addition, this is the first report of a seed germination protocol capable of forming L. ovallei rhizomes, which also remained viable even after two years. In summary, our study provides an in vitro and ex vitro method that could contribute to the conservation and preservation of this iconic species of Chile. Potentially, this method might be useful for other endangered geophytes of arid lands.

\section{Additional files}

Additional file 1: Graphical diagram showing the methodology applied for the sexual and asexual propagation of $L$. ovallei. A) Inflorescences of $L$. ovallei growing in Llanos de Challe National Park in November 2011. Bar= $10 \mathrm{~cm}$. B) Inflorescence of $L$. ovallei covered with a paper bag (December 2011). $\mathrm{Bar}=5 \mathrm{~cm}$. C) Healthy state of inflorescences and their seeds after two months covered with the paper bag (February 2012). Bar $=1 \mathrm{~cm}$. D) One-month old seedling growing inside a petri dish. $B a r=1 \mathrm{~cm}$. E) Threemonth old seedlings transplanted to ex vitro conditions. Young seedlings were covered with a plastic cup to protect them against dehydration; this plastic cup was opened to permit aeration. Bar $=2 \mathrm{~cm}$. F) Group of acclimated five-month old seedlings. Bar $=5 \mathrm{~cm}$. (JPG $1867 \mathrm{~kb}$ )

Additional file 2: Information on the baseline conditions used for in vitro seed germination analysis of $L$. ovallei seeds. Both in vitro cultivation conditions and pre-sowing treatments were evaluated using approximately 4000 seeds in total. (DOCX $18 \mathrm{~kb}$ )

Additional file 3: Rhizome production and multiplication of $L$. ovallei rhizomes. A) Rhizomes obtained from an eight-month old seedling. Bar = $1 \mathrm{~cm}$. B) Eight rhizomes each with its food storage organ obtained from one plant. Bar $=1 \mathrm{~cm}$. C) Rhizome dissection using a scalpel. Bar $=1 \mathrm{~cm}$. D) Dormant rhizomes of $L$. ovallei reactivated after two years of resting. $\mathrm{Bar}=1 \mathrm{~cm}$. (JPG $1675 \mathrm{~kb}$ )

Additional file 4: Monthly distribution of temperatures (T) and relative humidity (RH) in La Serena during years the 2014, 2015 and 2016. Data were obtained from Meteorological Station "La Serena", which is controlled by the Center for Advanced Studies in Arid Areas (CEAZA, wnw.ceazamet.cl). This station is installed at 50 meters from where this study was performed. (DOCX $16 \mathrm{~kb}$ )

Additional file 5: Physico-chemical analysis of La Serena tap water* (DOCX $16 \mathrm{~kb}$ )

\section{Acknowledgements}

We thank Mr. Mario Meléndez, Isla Troncoso and other national authorities of CONAF for providing the necessary facilities to collect seeds of. L. ovallei in the Llanos de Challe National Park. We are also very grateful to the Llanos de Challe National Park Rangers and Paloma Gachón for their valuable help during the seed collection procedures. We thank Dr. Julio Gutiérrez for his insightful comments and suggestions. We thank the Centre for Advanced Studies in Arid Zones (CEAZA) for providing their flow chamber and autoclave during the first stages of this study. We also thank Dirección de Investigación y Desarrollo Office of Universidad de La Serena for its economic support in the same stages of this research. We are grateful to Dr. Karina Stucken for her help in revising English grammar usage in this paper.

\section{Funding}

This work was funded by Fondo de Investigación en Bosque Nativo, grant $n^{\circ}$ 037/2011.

\section{Availability of data and materials}

The dataset generated and/or analysed during the current study is maintained in the personal repository of the corresponding author. Request for information should be sent by email to cibanez@userena.cl.

\section{Authors' contributions}

$\mathrm{FJ}, \mathrm{JB}$ and $\mathrm{Cl}$ collected the seeds. MV and EJ developed the in vitro protocol and rhizome production. CN performed the statistical analysis. Cl-B provided feedback during manuscript writing, and $\mathrm{Cl}$ conceived and coordinated all of the study, including legal aspects related to the collection of seeds, acted as the research supervisor and wrote the manuscript. All authors approved the final manuscript.

Ethics approval and consent to participate

Not applicable.

\section{Competing interests}

The authors declare that they have no competing interests.

\section{Publisher's Note}

Springer Nature remains neutral with regard to jurisdictional claims in published maps and institutional affiliations.

\section{Author details}

'Departamento de Biología, Facultad de Ciencias, Universidad de La Serena, P.O. 1700000 La Serena, Chile. ${ }^{2}$ Departamento de Matemáticas, Facultad de Ciencias, Universidad de La Serena, P.O. 1700000 La Serena, Chile. ${ }^{3}$ Instituto Tecnológico de Tepic, Avenida Tecnológico 2595, Lagos del Country, P.O. 63175 Tepic-Nayarit, Mexico. ${ }^{4}$ Departamento de Química, Facultad de Ciencias, Universidad de La Serena, P.O. 1700000 La Serena, Chile. ${ }^{5}$ Núcleo de Investigación en Producción Alimentaria, Facultad de Recursos Naturales, Escuela de Agronomía, Universidad Católica de Temuco, P.O. 4810721 Temuco, Chile.

Received: 29 June 2017 Accepted: 19 April 2018

Published online: 24 April 2018

\section{References}

1. Transeau EN. General botany. New Delhi: Discovery Publishing House; 1994. p. 560

2. Farahmand $\mathrm{H}$, Nazari F. Environmental and anthropogenic pressures on geophytes of Iran and the possible protection strategies: a review. Inter J of Horti Sci and Tech. 2015;2:111-32.

3. Sharma IK, Jones $D$, French $C$. Unusually high genetic variability revealed through allozymic polymorphism of an endemic and endangered Australian orchid, Pterostylis aff. Picta (Orchidaceae). Biochem Syst Ecol. 2003;31:513-26.

4. Muñoz M, Moreira A. Géneros endémicos de monocotiledóneas de Chile continental. Chile: Registro propiedad intelectual n 114.968; 2000. http:// www.chlorischile.cl/monocotiledoneas/Resultados.htm.

5. Wilkin P. Leonthochir ovallei, Alstroemeriaceae. Curtis's Bot Mag. 1997;14:7-12.

6. Gutiérrez J. El Desierto Florido en la Región de Atacama. In: Squeo FA, Arancio G, Gutiérrez JR, editors. Libro rojo de la flora nativa y de los sitios prioritarios para su conservación. Región de Atacama. La Serena: Ediciones Universidad de La Serena; 2008. p. 285-91.

7. Arancio G, Marticorena A. Descripción de las especies con problemas de conservación en la región de Atacama. In: Squeo FA, Arancio G, Gutiérrez $J R$, editors. Libro rojo de la flora nativa y de los sitios prioritarios para su conservación. La Serena: Ediciones Universidad de La Serena; 2008. p. 466.

8. Muñoz M, Serra MT. Documento de trabajo. Estado de conservación de las plantas de Chile. Santiago: MNHN-CONAMA; 2006.

9. IUCN. Categorías y criterios de la lista roja de la UICN: Versión 3.1. Comisión de supervivencia de especies de la UICN. Suiza y Cambridge, Reino Unido: Gland: UICN; 2001. p. 1.

10. CONAMA. Comité clasificación de especies silvestres. Acta Sesión $N^{\circ} 6$, segundo proceso de clasificación. Santiago: Comisión nacional de medio ambiente; 2006.

11. Hoffmann AE. Sinopsis taxonómica de las geófitas monocotiledóneas chilenas y su estado de conservación. In: Benoit I, editor. Libro rojo de la flora terrestre. Santiago: CONAF; 1989. p. 147-57.

12. Ravenna P, Teillier S, Macaya J, Rodríguez R, Zöllner O. Categorías de conservación de las plantas bulbosas nativas de Chile. In: Boletín del museo nacional de historia natural. 1998;47:47-68.

13. MINSEGPRES. Ministerio secretaría general de la presidencia, Decreto Supremo n 50/2008. Santiago; 2008. http://www.conaf.cl/cms/editorweb/ GEF-BM/Apendice-7_03-Clasificacion_Especies_segun_estado_conservacion/ DS_50-2008-SEGPRES.pdf.

14. Squeo FA, Arancio G, Gutiérrez JR, Letelier L, Arroyo MTK, León-Lobos, et al. Sitios prioritarios para la conservación de la flora nativa amenazada de la 
región de Atacama. In: Meléndez M, Peña A, Jara G, Louit C, editors. Flora amenazada de la región de Atacama y estrategias para su conservación. La Serena: Ediciones Universidad de La Serena; 2008. p. 29-44.

15. Bridgen MP, Olate E, Schiappacasse F. Flowering geophytes from Chile. In: Littlejohn $\mathrm{G}$, editor. Proceedings of the 8 th international symposium on flowerbulbs, vol. 570. Acta Hortic: ISHS; 2002. p. 75-80.

16. León-Lobos P, Rosas M, Guerrero PC, Sandoval A, Way M. Conservación ex situ de la flora de la región de Atacama: Métodos, experiencias y desafíos futuros. In: Squeo FA, Arancio G, Gutiérrez JR, editors. Libro rojo de la flora nativa y de los sitios prioritarios para su conservación: región de Atacama. La Serena: Ediciones Universidad de la Serena; 2008. p. 347-56.

17. Lu C, Ruan Y, Bridgen M. Micropropagation procedures for Leontochir ovallei. Plant Cell Tiss Org. 1995;42:219-21.

18. King JJ, Bridgen MP. Environmental and genotypic regulation of Alstroemeria seed germination. HortSci. 1990;25:1607-9.

19. Pedersen C, Hansen CW, Brandt K, Kristiansen K. Alstroemeria plantlets can be induced to flowering by cold treatment during in vitro culture. Sci Hort. 1996;66:217-28.

20. Buitendijk JH, Pinsonneaux N, van Donk AC, Ramanna MS, van Lammeren AAM. Embryo rescue by half-ovule culture for the production of interspecific hybrids in Alstroemeria. Sci Hort. 1995;64:65-75.

21. Lu C, Bridgen MP. Effects of genotype, culture medium and embryo developmental stage on the in vitro responses from ovule cultures of interspecific hybrids of Alstroemeria. Plant Sci. 1996;116:205-12.

22. Lin H-S, De Jeu MJ, Jacobsen E. The application of leafy explant micropropagation protocol in enhancing the multiplication efficiency of Alstroemeria. Sci Hort. 2000:85:307-18.

23. Aros $D$, Vásquez $M$, Rivas $C$, Prat ML. An efficient method for in vitro propagation of Alstroemeria pallida Graham rhizomes. Chilean J Agric Res. 2017:77:95-9.

24. De Klerk GJ, ter Brugge J. Micropropagation of Alstroemeria in liquid medium using slow release of medium components. Propagation Ornamental Plants. 2010;10:246-52.

25. Ebrahim MKH. Comparison, determination and optimizing the conditions required for rhizome and shoot formation, and flowering of in vitro cultured calla explants. Sci Hort. 2004;101:305-13.

26. Baskin CC, Baskin JM. Seeds: ecology, biogeography and evolution of dormancy and germination. 1st ed. San Diego, CA: Academic Press; 1998.

27. Grau J. Las monocotiledóneas petaloideas de Chile. In: Grau J, Zizka G, editors. Flora Silvestre de Chile, Sonderheft 19. Frankfurt am Main: Palmengarten; 1992. p. 97-101.

28. Muñoz C. Flores silvestres de Chile. München: Universidad de Chile; 1966. p. 245

29. Muñoz M, Schick M. Novedades en la familia Alstromeriaceae. Gayana Bot. 2000:57:55-9.

30. Sanso AM, Xifreda CC. Generic delimitation between Alstroemeria and Bomarea (Alstroemeriaceae). Ann Bot. 2001;88:1057-69.

31. ABTAO. Foto-reportaje. Desierto Florido (2011). Explosión de vida en el desierto de Atacama - Chile. 2015. http://abtao.cl/site/2011/11/09/fotoreportaje-desierto-florido-2011-explosion-de-vida-en-el-desierto-deatacama-chile. Accessed 15 Nov 2011.

32. Westphal C, Gachón P, Bravo J, Navarrate C, Salas C, Ibáñez C. The potential of Algarrobo (Prosopis chilensis (Mol.) Stuntz) for regeneration of desertified soils: assessing seed germination under saline conditions. Environ Manag. 2015;56:209-20.

33. Benjamini Y, Yekutieli D. The control of the false discovery rate in multiple testing under dependency. Ann Stat. 2001;29:1165-88.

34. Byrd RH, Lu P, Nocedal J, Zhu C. A limited memory algorithm for bound constrained optimization. SIAM J Sci Comput. 1995;16:1190-208.

35. Core R, Team. R. A language and environment for statistical computing. Vienna: R Foundation for Statistical Computing; 2017. https:/www.R-project.org/

36. Nikoleave MG. Factors controlling seed dormancy pattern. Amsterdam: NorthHolland publishing Co; 1977. p. 51-74.

37. Irwin PT. Plant physiology. Reading, MA: Addision-Wesley Publishing Company; 1982. p. 501-40.

38. Jackson MB. Root-to-shoot communication in flooded plants. Involvement of abscisic acid, ethylene and 1-aminocy clopropane-1-carboxylic acid. Agron J. 1994;86:775-81.

39. Baskin JM, Baskin CC. Methods of breaking seed dormancy in the endangered species Iliamna corei (Sherff) Sherff (Malvaceae), with special attention to heating. Nat Areas J. 1997;17:313-23.
40. Rao KN, Janson J, Ehsan DM, Ghosch K, Nowell D, Larinde M. Handbooks for GeneBank n8. Manual of seed handling in genebanks. Rome: Biodiversity International; 2006.

41. Schiappacasse $F$, Peñailillo $P$, Yáñez $P$, Bridgen M. Propagation studies on chilean geophytes. Acta Hortic. 2005;673:121-6.

42. Nasri F, Koshesh Saba M, Ghaderi N, Akbar Mozafari A, Javadi T. Improving germination and dormancy breaking in Alstromeria ligtu hybrid seeds. Trakia J Sci. 2014;1:38-46.

43. Borisjuk L, Macherel D, Benamar A, Wobus U, Rolletschek H. Low oxygen sensing and balancing in plant seeds: a role for nitric oxide. New Phytol. 2007:176:813-23.

44. Smýkal P, Vernoud V, Blair MW, Soukup A, Thompson RD. The role of the testa during development and in establishment of dormancy of the legume seed. Front Plant Sci. 2014:5:351.

45. Young JA, Young CG. Seeds of woody plants in North America. Portland, OR: Dioscorides Press; 1992.

46. Dekker J, Hargrove M. Weedy adaptation in Setaria spp. V. Effects of gaseous environment on giant foxtail (Setaria faberii) (Poaceae) seed germination. Am J Bot. 2002;89:410-6.

47. Vigeolas H, van Dongen JT, Waldeck P, Huhn D, Geigenberger P. Lipid storage metabolism is limited by the prevailing low oxygen concentrations within developing seeds of oilseed rape. Plant Physiol. 2003;133:2048-60.

48. Weitbrecht K, Müller K, Leubner-Metzger G. First off the mark: early seed germination. J Exp Bot. 2011;62:3289-309.

49. Yu Y, Guo G, Lu D, Hu Y, Li J, Li X, et al. Transcriptome analysis during seed germination of elite Chinese bread wheat cultivar Jimai 20. BMC Plant Biol. 2014;14:20.

50. El-Maarouf-Bouteau H, Bailly C. Oxidative signaling in seed germination and dormancy. Plant Signal Behav. 2008;3:175-82.

51. Borisjuk $L$, Rolletschek $H$. The oxygen status of the developing seed. New Phytol. 2008;182:17-30.

52. Miranda RQ, Oliveira MTP, Correia RM, Almeida-Cortez JS, Pompelli MF. Germination of Prosopis juliflora (Sw) DC seeds after scarification treatments. Plant Spec Biol. 2011;26:186-92.

53. Nasr SMH, Savadkoohi SK, Ahmadi E. Effect of different seed treatments on dormancy breaking and germination in three species in arid and semi-arid lands. For Sci Pract. 2013:15:130-6.

54. Ruter JM, Ingram DL. Germination and morphology of Sophora secundiflora seeds following scarification. Hortscience. 1991;26:256-7.

55. Machuca AP. Efecto de la estratificación de embriones y escarificación de semillas sobre el crecimiento de Alstroemeria spp. in vitro. Tesis Ingeniero Agrónomo. Facultad de Ciencias Agronómicas. Santiago: Universidad de Chile; 2006.

56. Masamba C. Presowing seed treatments on four African Acacia species: appropriate technology for use in forestry for rural development. Forest Ecol Manag. 1994;64:105-9.

57. Gupta R, Chakrabarty SK. Gibberellic acid in plant: still a mystery unresolved. Plant Signal Behav. 2013:8:e25504.

58. Ogawa M, Hanada A, Yamauchi Y, Kuwahara A, Kamiya Y, Yamaguchi S. Gibberellin biosynthesis and response during Arabidopsis seed germination. Plant Cell. 2003;15:1591-604

59. Finch-Savage WE, Leubner-Metzger G. Seed dormancy and the control of germination. New Phytol. 2006;171:501-23.

60. Mroginski L, Sansberro P, Flaschland E. Establecimiento de cultivos de tejidos vegetales. In: Levitus G, Echenique V, Rubinstein C, Hopp E, Mroginski L, editors. Biotecnología y mejoramiento vegetal Il; 2010. p. 17-25.

61. Nasri F, Mortazasvi S, Ghaderi N, Javadi T. Propagation in vitro of Alstroemeria ligtu hybrid through direct organogenesis from leaf base. J Hort Res. 2013:21:23-30.

62. Kristiansen K, Ørnstrup H, Brandt K. In vitro PPFD and media composition affect both in and ex vitro performance of Alstroemeria butterfly-hybrids. Plant Cel Tiss Org. 1999;56:145-53.

63. Chiari A, Bridgen MP. Rhizome splitting: a new micropropagation technique to increase in vitro propagule yield in Alstroemeria. Plant Cell Tissue Organ Cult. 2000;62:39-46.

64. Cepeda-Pizarro J, Pizarro-Araya J, Vásquez H. Abundance and composition of epigean arthropods from llanos de challe national park: impacts of ENSO-1997 and effects of the pedological habitat. Rev Chil His Nat. 2005;78:635-50. 